The Canadian Journal of Information and Library Science

La Revue canadienne des sciences de l'information et de

bibliothéconomie

\title{
Trends in authorship by women at Canadian universities 2006
} to 2019

\section{Tendances d'autorat par les femmes dans les universités canadiennes entre 2006 et 2019}

\section{Jeffrey Demaine}

Volume 44, numéro 2-3, 2021

URI : https://id.erudit.org/iderudit/1085233ar

DOI : https://doi.org/10.5206/cjilsrcsib.v44i2.13687

\section{Aller au sommaire du numéro}

\section{Éditeur(s)}

Canadian Association for Information Science - Association canadienne des sciences de l'information

\section{ISSN}

1195-096X (imprimé)

1920-7239 (numérique)

Découvrir la revue

\section{Citer cet article}

Demaine, J. (2021). Trends in authorship by women at Canadian universities 2006 to 2019. The Canadian Journal of Information and Library Science / La Revue canadienne des sciences de l'information et de bibliothéconomie, 44(2-3), 1-11. https://doi.org/10.5206/cjilsrcsib.v44i2.13687
Résumé de l'article

Malgré de nombreux progrès depuis le milieu du 20e siècle, il existe toujours une disparité entre le nombre de femmes et d'hommes dans le milieu universitaire. Les récentes mesures pour favoriser la diversité et l'inclusion par les universités ont augmenté l'attention portée à ce fossé de genres. En mesurant les métadonnées des publications universitaires, la bibliométrie permet de mettre en lumière la disparité de genres en recherche. En mesurant le ratio femmes/hommes auteurs, le biais de genre à l'échelle des institutions de recherche peut être quantifié. Cette étude examine la proportion de femmes auteurs d'articles universitaires dans trente universités canadiennes dans cinq grands domaines de recherche. (c) Jeffrey Demaine, 2021

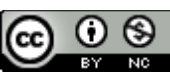

Ce document est protégé par la loi sur le droit d'auteur. L'utilisation des services d'Érudit (y compris la reproduction) est assujettie à sa politique d'utilisation que vous pouvez consulter en ligne.

https://apropos.erudit.org/fr/usagers/politique-dutilisation/ 


\title{
Trends in authorship by women at Canadian universities 2006 to 2019
}

\section{Tendances d'autorat par les femmes dans les universités canadiennes entre 2006 et 2019}

\section{Jeffrey Demaine}

McMaster University

\begin{abstract}
Despite much progress since the mid-20th century, there still exists a disparity in the number of female academics relative to their male colleagues. This gender gap has come under increased focus as universities take steps to foster diversity and inclusiveness. Bibliometrics can provide a window into the gender disparity in research by measuring the metadata of academic publications. By determining the ratio of female to male authors, the gender bias at the level of the institution can be quantified. This study examines the proportion of female authors of academic articles at thirty Canadian universities across five broad fields of research.
\end{abstract}

Keywords: gender, bibliometrics, authorship, Canada, universities

Résumé : Malgré de nombreux progrès depuis le milieu du $20^{\mathrm{e}}$ siècle, il existe toujours une disparité entre le nombre de femmes et d'hommes dans le milieu universitaire. Les récentes mesures pour favoriser la diversité et l'inclusion par les universités ont augmenté l'attention portée à ce fossé de genres. En mesurant les métadonnées des publications universitaires, la bibliométrie permet de mettre en lumière la disparité de genres en recherche. En mesurant le ratio femmes/hommes auteurs, le biais de genre à l'échelle des institutions de recherche peut être quantifié. Cette étude examine la proportion de femmes auteurs d'articles universitaires dans trente universités canadiennes dans cinq grands domaines de recherche.

Mots clés : genre, bibliométrie, autorat, Canada, universités

\section{Background}

Academia was once the preserve of men. Until the sweeping cultural changes of the 1960s, few women pursued a career in higher education. As societal attitudes have evolved over the past several decades, women have come to make up an increasing portion of the professoriate such that there is now parity at some institutions. For example, there is an equal balance of men and women in the faculty of anthropology at 
the University of California at Los Angeles (UCLA 2017). While illustrative, an analysis of gender distribution at the national level cannot rely on such anecdotal studies.

Because it is impractical to obtain the demographics of faculty employed by each institution, the bibliographic metadata of articles can serve as a proxy in measuring the gender distribution at the authors' affiliated institutions. A report produced by Elsevier on global patterns in the gender of researchers identifies authors based on their names and compares the proportion of women to men in academia across subject areas and countries. At such high levels of data aggregation, nuances in the structure of scholarly communication become visible, such as that women tend to publish research that is more highly interdisciplinary than that of men, and yet also that women tend to not publish as many articles involving international collaboration as do men (Elsevier 2017).

By counting the authors of academic articles with female names, some recent studies have been able to identify a gender bias at the level of a field of study such as Chemistry (Annesley 2020), Ophthalmology (Kramer et al. 2019), and Computer Science (Mattauch et al. 2020). Overall, there remains a distinct gap in the participation of women relative to men in academia, particularly in the natural sciences. This pattern exists globally (Larivière et al. 2013) and is observed across many fields (Huang et al. 2020). Other studies have addressed the disparity between the number of female and male authors in science at the national level. Examples include Turkey (Erden Aki et al. 2015), Russia (Paul-Hus et al. 2015), and Canada (Goldstone et al. 2020).

Yet it is where parity exists that helps to explain the gender gap found in other aspects of scholarly communication. Notably, the gender gap in the number of academics who are women and how much they publish is uncorrelated with the impact they have: Lynn et al. (2019) found that there is no difference in the number of citations received by articles written by women as compared to those written by men. Similarly, a large study of trends in authorship found two features that do not vary between genders: that male and female authors have the same annual rate of production, and that they have the same amount of citation impact for a given amount of output (Huang et al. 2020). It is against this background that a contrast between men and women emerges. The same study found that despite the increase of women in academia from 1955 to 2010, differences in career length between men and women have resulted in an increasing gender gap in both productivity and impact. The careers of women tend to include more and longer interruptions than those of men. Despite a parity of output on an annual basis, these interruptions result in a shorter overall career length and therefore less overall output and less impact over the long term.

Over a more recent time frame, a global study by Elsevier of scholarly output found that during the five-year periods 1996-2000 and 2011-2015, men produced more publications than women in all countries studied (except Japan). Paradoxically, despite the increase in the ratio of women to men in research, the average productivity of Canadian women researchers actually declined in the decade between 1996-2000 to 2011-2015 from 2.0 articles to 1.9. The report surmises that career breaks may impact the productivity of women researchers over the long term (Elsevier 2017, 28-29). Thus, the gender gap is one of opportunity, not ability. The differences in the output of female authors reflect the structural barriers they face relative to men, or the personal 
choices of individuals when aggregated at the population level. Overall, positive changes in the number of authors who are women at a given university over time are indicative of that university's efforts to hire female academics as well as shifting sociocultural factors.

This study compares the rate of female authorship at the institutional level by comparing female authorship at thirty universities across Canada in five broad fields of research. These universities represent an exhaustive survey of the Canadian higher education sector, covering smaller institutions with a more regional focus (e.g., Brock University) to very large institutions ranked among the best in the world (e.g., the University of Toronto). At the same time these thirty universities offer a coherent sample of gender trends in the higher education sector as all are research-intensive institutions operating in the context of a country with a relatively small population.

\section{Methodology}

The data for 30 Canadian universities were extracted from the 2021 Leiden dataset (Centrum voor Wetenschap en Technologische Studies 2021), which is derived from the Web of Science's Science Citation Index Expanded, the Social Sciences Citation Index, and the Arts \& Humanities Citation Index. The extracted data covers eleven periods of four years each, from 2006-2009 to 2016-2019. As this dataset is used for measuring research impact, these four-year publication windows serve to smooth out yearly fluctuations. Only article and review document types are considered in the Leiden dataset. The articles measured by this dataset are grouped by subject area, with a sixth category "All sciences" providing the average of these five broad areas of research:

- Biomedical \& health sciences

- Life and earth sciences

- Mathematics \& computer science

- Physical sciences \& engineering

- Social sciences \& humanities

The Leiden dataset lists the proportion of female to male authors in the field "PA_F_MF." This metric reflects the percentage of authors who are women as calculated from the total number of author names that can be identified as either male or female. Note that this total does not include authors for whom a gender could not be deduced from their name, which represent $20 \%$ of all names in the Leiden dataset. Thus, this study assumes that there is no bias in the unclassifiability of male and female names and that consequently the observed ratio of female to male authors in the $80 \%$ of names that are disambiguated is representative of the whole population of authors at a given university. While many of the studies mentioned in the Introduction examined the relative number of women appearing as first author or last author, the data discussed here does not make that distinction, and all instances of authorship are counted, regardless of position. Indeed, as some research fields place no importance on the order of authorship, it would be incorrect to compare the rate of first or last authorship between fields. 
In counting authorship for the purpose of assigning gender, the Leiden dataset uses full (whole) counting, and not fractional counting of publications. This means that for an article having multiple co-authors, each receives credit for having written one article. In contrast, fractional counting divides the credit for a publication between its authors, such that each is credited with having written a certain fraction of the article. A fractional counting of publications is available in the Leiden dataset, but is not used in the context of counting authorship by gender. One man and one woman may co-author an article, with each receiving credit for one-half of the publication, but it is illogical to express the gender of each co-author as a fraction: the article was not written by half a man and half a woman.

\section{Results}

\section{Trends in gender disparity over the decade}

Behind the position of these universities at the final time period, the change over the eleven years covered by the data revealed interesting trends. For each university, the slope of a linear regression across the eleven time periods shows the percentage change in female authorship per year (see Table 1: "Trend/year"). Ranked by this measure, we see that the institution that has made the most progress is the Institut Nationale de la Recherche Scientifique (INRS), which began the decade with a highly male-dominated faculty, having only $15.6 \%$ female authors in 2006-2009. It has increased this proportion by $79.1 \%$ to $28.0 \%$ in $2016-2019$. The slope of the linear regression over the eleven periods studied shows that the INRS increased its proportion of female authors by $1.2 \%$ per year. More mainstream universities that also show a strong positive trend include Ryerson University $(0.9 \%)$, the University of Calgary $(0.71 \%)$, and Brock University $(0.69 \%)$. At the other end of the spectrum three institutions show a slightly negative trend over the decade: Memorial University of Newfoundland remained almost unchanged $(-0.03 \%)$, while the University of Victoria declined by $-0.11 \%$. This seemingly insignificant number actually represents a considerable decline relative to the other universities because the country saw an average increase of $19.3 \%$ in the proportion of female authors between 2006-2009 and 2016-2019 (see Table 2). Note that the University of Victoria also had the highest percentage of unclassified names, and thus the observed decline in female authorship may be due to poor coverage in the dataset.

\begin{tabular}{|c|c|c|c|c|c|c|c|c|c|c|c|c|c|}
\hline University & Rank & $\begin{array}{l}2006- \\
2009\end{array}$ & $\begin{array}{l}2007- \\
2010\end{array}$ & $\begin{array}{l}2008- \\
2011\end{array}$ & $\begin{array}{l}2009- \\
2012\end{array}$ & $\begin{array}{l}2010- \\
2013\end{array}$ & $\begin{array}{l}2011- \\
2014\end{array}$ & $\begin{array}{l}2012- \\
2015\end{array}$ & $\begin{array}{l}2013- \\
2016\end{array}$ & $\begin{array}{l}2014- \\
2017\end{array}$ & $\begin{array}{l}2015- \\
2018\end{array}$ & $\begin{array}{l}2016- \\
2019\end{array}$ & $\begin{array}{l}\text { Trend } \\
\text { / year }\end{array}$ \\
\hline INRS & 1 & $15.6 \%$ & $17.5 \%$ & $18.2 \%$ & $19.7 \%$ & $21.9 \%$ & $21.9 \%$ & $23.1 \%$ & $23.9 \%$ & $25.2 \%$ & $27.0 \%$ & $28.0 \%$ & $1.19 \%$ \\
\hline University of Calgary & 3 & $27.4 \%$ & $27.6 \%$ & $27.7 \%$ & $28.6 \%$ & $29.5 \%$ & $30.5 \%$ & $31.0 \%$ & $31.7 \%$ & $32.7 \%$ & $33.1 \%$ & $34.2 \%$ & $0.71 \%$ \\
\hline Brock University & 4 & $33.1 \%$ & $35.5 \%$ & $36.4 \%$ & $37.9 \%$ & $38.7 \%$ & $38.1 \%$ & $38.3 \%$ & $38.7 \%$ & $39.8 \%$ & $40.9 \%$ & $41.6 \%$ & $0.69 \%$ \\
\hline University of Regina & 5 & $24.3 \%$ & $25.9 \%$ & $26.1 \%$ & $25.6 \%$ & $25.8 \%$ & $25.2 \%$ & $26.0 \%$ & $29.3 \%$ & $29.9 \%$ & $30.1 \%$ & $32.0 \%$ & $0.68 \%$ \\
\hline University of Waterloo & 7 & $18.4 \%$ & $19.5 \%$ & $19.8 \%$ & $20.8 \%$ & $21.8 \%$ & $22.1 \%$ & $22.8 \%$ & $22.9 \%$ & $23.3 \%$ & $24.1 \%$ & $24.4 \%$ & $0.58 \%$ \\
\hline University of Guelph & 8 & $31.5 \%$ & $32.0 \%$ & $31.9 \%$ & $33.2 \%$ & $33.9 \%$ & $34.1 \%$ & $34.8 \%$ & $35.0 \%$ & $35.7 \%$ & $36.2 \%$ & $37.6 \%$ & $0.58 \%$ \\
\hline Queen's University & 9 & $28.8 \%$ & $29.7 \%$ & $30.2 \%$ & $30.7 \%$ & $31.5 \%$ & $31.8 \%$ & $32.0 \%$ & $32.8 \%$ & $33.2 \%$ & $34.0 \%$ & $35.1 \%$ & $0.56 \%$ \\
\hline
\end{tabular}




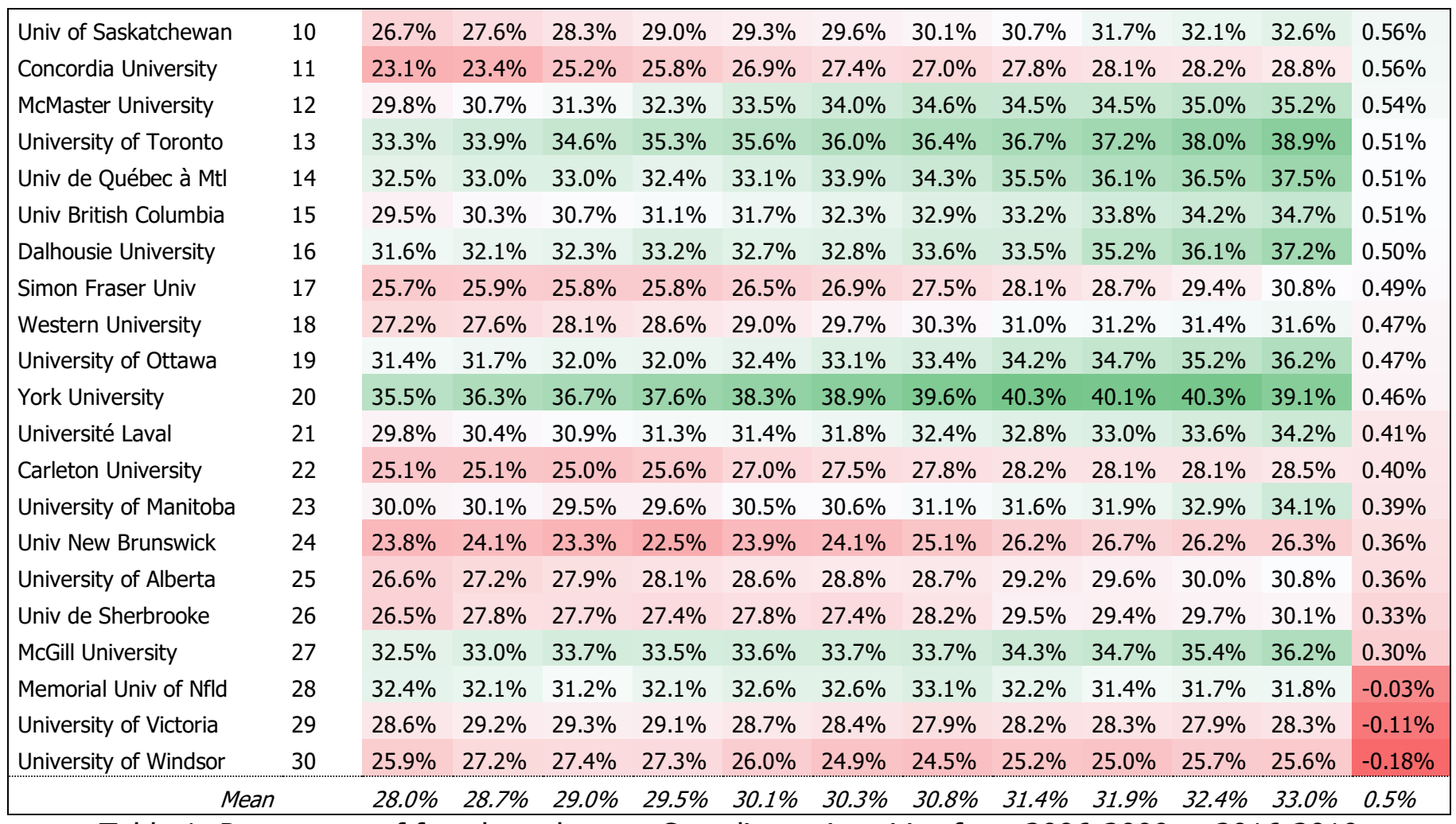

Table 1: Percentage of female authors at Canadian universities from 2006-2009 to 2016-2019 The trend gives the average change per year over the eleven periods.

Table 2 shows the relative changes in female authorship over the course of the course of eleven years. On average, Canadian universities increased their proportion of female researchers by $19.3 \%$. This indicates that the increase in female authors is a general trend across the Canadian higher education sector and that the relative proportion of female academics is a characteristic of each institution. A comparison of the ranking of these universities at the beginning and the end of the decade shows a strong correlation between their rankings (Spearman's rho $=0.8585$, $p$-value (twotailed) < 0.001). Those universities that had many female authors in 2006-2009 tended to also have a high number in 2016-2019. In this context, large gains in the proportion of female authorship reveal strategic efforts on the part of a university to address the gender gap.

\begin{tabular}{|l|cc|ccc|cc|}
\hline \multicolumn{1}{|c}{ University } & \multicolumn{6}{c|}{ Percentage of Female Authors } \\
& $\mathbf{2 0 0 6 - 0 9}$ & Rank & $\mathbf{2 0 1 6 - 1 9}$ & Rank & Change & Rank \\
\hline INRS & $15.6 \%$ & 30 & $28.0 \%$ & 27 & $79.7 \%$ & 1 \\
Ryerson University & $22.9 \%$ & 28 & $32.4 \%$ & 17 & $41.5 \%$ & 2 \\
University of Waterloo & $18.4 \%$ & 29 & $24.4 \%$ & 30 & $32.5 \%$ & 3 \\
University of Regina & $24.3 \%$ & 25 & $32.0 \%$ & 18 & $31.8 \%$ & 4 \\
Brock University & $33.1 \%$ & 3 & $41.6 \%$ & 1 & $25.8 \%$ & 5 \\
Concordia University & $23.1 \%$ & 27 & $28.8 \%$ & 24 & $25.1 \%$ & 6 \\
University of Calgary & $27.4 \%$ & 17 & $34.2 \%$ & 13 & $24.9 \%$ & 7 \\
Univ Saskatchewan & $26.7 \%$ & 19 & $32.6 \%$ & 16 & $21.9 \%$ & 8 \\
Queen's University & $28.8 \%$ & 15 & $35.1 \%$ & 11 & $21.8 \%$ & 9 \\
\hline
\end{tabular}




\begin{tabular}{|l|cc|cc:c|c}
\hline Simon Fraser Univ & $25.7 \%$ & 23 & $30.8 \%$ & 22 & $19.9 \%$ & 10 \\
Université de Montréal & $31.1 \%$ & 10 & $37.3 \%$ & 6 & $19.8 \%$ & 11 \\
University of Guelph & $31.5 \%$ & 8 & $37.6 \%$ & 4 & $19.4 \%$ & 12 \\
McMaster University & $29.8 \%$ & 12 & $35.2 \%$ & 10 & $18.1 \%$ & 13 \\
Dalhousie University & $31.6 \%$ & 7 & $37.2 \%$ & 7 & $17.6 \%$ & 14 \\
Univ of British Columbia & $29.5 \%$ & 14 & $34.7 \%$ & 12 & $17.4 \%$ & 15 \\
University of Toronto & $33.3 \%$ & 2 & $38.9 \%$ & 3 & $17.1 \%$ & 16 \\
University of Alberta & $26.6 \%$ & 20 & $30.8 \%$ & 21 & $16.1 \%$ & 17 \\
Western University & $27.2 \%$ & 18 & $31.6 \%$ & 20 & $16.1 \%$ & 18 \\
Univ de Québec à Mtl & $32.5 \%$ & 4 & $37.5 \%$ & 5 & $15.4 \%$ & 19 \\
University of Ottawa & $31.4 \%$ & 9 & $36.2 \%$ & 9 & $15.1 \%$ & 20 \\
Université Laval & $29.8 \%$ & 13 & $34.2 \%$ & 14 & $14.7 \%$ & 21 \\
University of Manitoba & $30.0 \%$ & 11 & $34.1 \%$ & 15 & $13.7 \%$ & 22 \\
Univ Sherbrooke & $26.5 \%$ & 21 & $30.1 \%$ & 23 & $13.7 \%$ & 23 \\
Carleton University & $25.1 \%$ & 24 & $28.5 \%$ & 25 & $13.4 \%$ & 24 \\
McGill University & $32.5 \%$ & 5 & $36.2 \%$ & 8 & $11.5 \%$ & 25 \\
Univ of New Brunswick & $23.8 \%$ & 26 & $26.3 \%$ & 28 & $10.6 \%$ & 26 \\
York University & $35.5 \%$ & 1 & $39.1 \%$ & 2 & $10.1 \%$ & 27 \\
University of Victoria & $28.6 \%$ & 16 & $28.3 \%$ & 26 & $-0.9 \%$ & 28 \\
University of Windsor & $25.9 \%$ & 22 & $25.6 \%$ & 29 & $-1.3 \%$ & 29 \\
Memorial Univ Nfld & $32.4 \%$ & 6 & $31.8 \%$ & 19 & $-2.1 \%$ & 30 \\
\hline
\end{tabular}

Table 2: Change in percentage of female authors at Canadian universities: 2006-2009 to 2016-2019

\section{Large differences between research fields}

While these summary statistics provide a snapshot of the overall gender distribution across universities, one must look into the gender balance at the field level in order to better understand where female academics are concentrated, and where their numbers are growing the most. Table 3 shows the ratio of female to male authors for the latest time period (2016-2019) and provides an overview of the gender gap in Canadian universities as viewed through the lens of five research fields. Table 3 ranks these universities by the summary field "All sciences", for which the average proportion of female authorship is $33.0 \%$.

For example, the Social Sciences \& Humanities has an almost equal balance with $48.4 \%$ of authors being female. Similarly, Biomedical \& Health Sciences has a large proportion of female authors at $42.0 \%$. At the other end of the spectrum, the most male-dominated fields of research were Mathematics \& Computer Science and Physical Sciences \& Engineering, which show (respectively) an average of only $15.6 \%$ and $18.0 \%$ of female authors across these 30 universities in the latest period. These figures match those found in a study of authorship worldwide which found that by $200515.1 \%$ of authors in Mathematics and 17.6\% in Engineering were female (Huang et al. 2020). This reveals that the proportion of researchers in Canadian universities who are women is representative of the global research community. It also suggests that, as gender distribution in the Social Sciences \& Humanities and Biomedical \& Health Sciences is at near parity, there is little room for increased participation of women in these fields. Consequently, if Canadian universities aim to achieve an overall balance between men 
and women in their faculties, the challenge will be to attract more women to pursue careers in the pure and applied sciences.

Fields such as Medicine have traditionally attracted a large number of female students, and it is logical that this would lead to a greater percentage of female researchers and professors. However, lack of a medical school is not the main driver of the gender gap. For example, neither Brock University, the Université du Québec à Montréal, nor the University of Waterloo have a medical school, yet these are ranked $1^{\text {st }}, 5^{\text {th }}$, and $30^{\text {th }}$ (last) in terms of having the most female authors. Thus, a medical school has no bearing on the rankings.

It should be noted that an understanding of the gender gap in the Physical sciences and engineering is hampered by the inability to categorize by gender a large proportion of names. As shown in Table 4, more than $50 \%$ of the names in this field are unclassifiable at four universities (bold text), which undermines the measurement of female authors at those institutions. Instead, this reveals the high level of non-Western names in that field, a characteristic quite distinct from gender.

\begin{tabular}{|c|c|c|c|c|c|c|c|}
\hline University & Rank & $\begin{array}{c}\text { All } \\
\text { sciences }\end{array}$ & $\begin{array}{c}\text { Biomedical } \\
\text { \& health } \\
\text { sciences }\end{array}$ & $\begin{array}{c}\text { Life \& } \\
\text { earth } \\
\text { sciences }\end{array}$ & $\begin{array}{l}\text { Mathematics } \\
\text { \& computer } \\
\text { science }\end{array}$ & $\begin{array}{c}\text { Physical } \\
\text { sciences \& } \\
\text { engineering }\end{array}$ & $\begin{array}{c}\text { Social } \\
\text { sciences \& } \\
\text { humanities }\end{array}$ \\
\hline Brock University & 1 & $41.6 \%$ & $46.4 \%$ & $38.1 \%$ & $17.2 \%$ & $24.4 \%$ & $49.1 \%$ \\
\hline York University & 2 & $39.1 \%$ & $50.9 \%$ & $34.5 \%$ & $23.0 \%$ & $13.0 \%$ & $53.6 \%$ \\
\hline University of Toronto & 3 & $38.9 \%$ & $41.0 \%$ & $37.2 \%$ & $18.2 \%$ & $20.5 \%$ & $51.4 \%$ \\
\hline University of Guelph & 4 & $37.6 \%$ & $45.0 \%$ & $35.6 \%$ & $19.3 \%$ & $24.8 \%$ & $48.3 \%$ \\
\hline Univ de Québec à Mtl & 5 & $37.5 \%$ & $50.7 \%$ & $30.7 \%$ & $12.5 \%$ & $23.8 \%$ & $57.4 \%$ \\
\hline Université de Montréal & 6 & $37.3 \%$ & $41.6 \%$ & $36.0 \%$ & $13.3 \%$ & $24.9 \%$ & $46.7 \%$ \\
\hline Dalhousie University & 7 & $37.2 \%$ & $40.1 \%$ & $35.2 \%$ & $15.4 \%$ & $23.2 \%$ & $55.1 \%$ \\
\hline McGill University & 8 & $36.2 \%$ & $40.1 \%$ & $34.2 \%$ & $15.7 \%$ & $18.5 \%$ & $49.3 \%$ \\
\hline University of Ottawa & 9 & $36.2 \%$ & $39.4 \%$ & $30.1 \%$ & $18.6 \%$ & $17.8 \%$ & $50.2 \%$ \\
\hline McMaster University & 10 & $35.2 \%$ & $38.4 \%$ & $31.9 \%$ & $15.6 \%$ & $20.8 \%$ & $49.2 \%$ \\
\hline Queen's University & 11 & $35.1 \%$ & $42.2 \%$ & $34.3 \%$ & $11.5 \%$ & $17.5 \%$ & $49.9 \%$ \\
\hline Univ of British Columbia & 12 & $34.7 \%$ & $39.3 \%$ & $33.4 \%$ & $14.9 \%$ & $16.8 \%$ & $46.5 \%$ \\
\hline University of Calgary & 13 & $34.2 \%$ & $38.2 \%$ & $31.1 \%$ & $15.7 \%$ & $15.9 \%$ & $51.2 \%$ \\
\hline Université Laval & 14 & $34.2 \%$ & $40.0 \%$ & $30.7 \%$ & $17.4 \%$ & $18.0 \%$ & $41.9 \%$ \\
\hline University of Manitoba & 15 & $34.1 \%$ & $37.8 \%$ & $29.2 \%$ & $15.5 \%$ & $17.5 \%$ & $52.6 \%$ \\
\hline Univ of Saskatchewan & 16 & $32.6 \%$ & $40.3 \%$ & $30.5 \%$ & $15.1 \%$ & $16.8 \%$ & $44.4 \%$ \\
\hline Ryerson University & 17 & $32.4 \%$ & $55.0 \%$ & $33.5 \%$ & $11.0 \%$ & $12.7 \%$ & $53.5 \%$ \\
\hline University of Regina & 18 & $32.0 \%$ & $48.1 \%$ & $29.3 \%$ & $13.0 \%$ & $19.8 \%$ & $48.6 \%$ \\
\hline Memorial Univ of Nfld & 19 & $31.8 \%$ & $40.4 \%$ & $31.2 \%$ & $16.3 \%$ & $18.4 \%$ & $46.5 \%$ \\
\hline Western University & 20 & $31.6 \%$ & $34.1 \%$ & $29.7 \%$ & $20.1 \%$ & $17.8 \%$ & $46.1 \%$ \\
\hline University of Alberta & 21 & $30.8 \%$ & $38.4 \%$ & $26.4 \%$ & $13.7 \%$ & $15.4 \%$ & $47.6 \%$ \\
\hline Simon Fraser Univ & 22 & $30.8 \%$ & $39.5 \%$ & $33.3 \%$ & $19.9 \%$ & $12.9 \%$ & $43.2 \%$ \\
\hline Univ de Sherbrooke & 23 & $30.1 \%$ & $39.8 \%$ & $30.5 \%$ & $11.6 \%$ & $8.6 \%$ & $57.9 \%$ \\
\hline Concordia University & 24 & $28.8 \%$ & $43.9 \%$ & $28.8 \%$ & $15.8 \%$ & $17.2 \%$ & $46.3 \%$ \\
\hline Carleton University & 25 & $28.5 \%$ & $36.0 \%$ & $30.9 \%$ & $6.7 \%$ & $18.2 \%$ & $48.0 \%$ \\
\hline University of Victoria & 26 & $28.3 \%$ & $41.4 \%$ & $31.3 \%$ & $21.3 \%$ & $13.8 \%$ & $45.7 \%$ \\
\hline INRS & 27 & $28.0 \%$ & $45.3 \%$ & $31.7 \%$ & $11.8 \%$ & $22.5 \%$ & $37.4 \%$ \\
\hline Univ of New Brunswick & 28 & $26.3 \%$ & $44.1 \%$ & $23.1 \%$ & $16.9 \%$ & $17.6 \%$ & $50.8 \%$ \\
\hline University of Windsor & 29 & $25.6 \%$ & $39.2 \%$ & $22.0 \%$ & $19.3 \%$ & $16.2 \%$ & $42.4 \%$ \\
\hline University of Waterloo & 30 & $24.4 \%$ & $42.3 \%$ & $27.6 \%$ & $11.7 \%$ & $14.2 \%$ & $40.1 \%$ \\
\hline
\end{tabular}


Table 3: Universities ranked by proportion of authors who are women (All sciences), 2016-2019

\section{Unclassified names}

Not all authors can be classified as being male or female. A researcher may choose to hide their gender by publishing with only a first initial rather than a full first name. In such cases, the author does not wish to be identified as either male or female and the inability of the algorithm used by CWTS in compiling the dataset to assign a gender is the correct outcome. However, it is more likely that authors are unclassifiable because their names do not conform to Western naming patterns. Such is the case with many Asian names.

By way of example, compare those universities with the highest rate of name disambiguation against those with the lowest rates and a regional pattern emerges. For the most recent time period, three of the four Francophone universities in Quebec have a very low percentage of unclassified authors (see Table 4). As the working language at these institutions is French, there is naturally a self-selection for faculty from the French-Canadian community. French personal names are quintessentially European, suggesting that the CWTS algorithm is quite accurate in disambiguating such names. In contrast, three universities in English Canada have a much lower rate of author name disambiguation. The University of Victoria, Carleton University, and Simon Fraser University are typical Canadian institutions, yet the gender of (respectively) $57.4 \%$, $49.4 \%$, and $48.8 \%$ of their authors remains unclassified. These averages hide the fact that the unclassifiable names at these three institutions occur overwhelmingly in the fields of Physical Science \& Engineering and Mathematics \& Computer Science. This is not a shortcoming of the data: the same algorithm successfully disambiguated names at a high rate in the Social Sciences \& Humanities at the very same institutions, with an average ratio of unclassifiability for these three $(7.7 \%)$ being even better than the Canadian average of $8.3 \%$ for this field.

\begin{tabular}{|lcccccc|}
\hline \multicolumn{1}{|c}{ University } & $\begin{array}{c}\text { All } \\
\text { sciences }\end{array}$ & $\begin{array}{c}\text { Biomedical } \\
\text { \& health } \\
\text { sciences }\end{array}$ & $\begin{array}{c}\text { Life \& } \\
\text { earth } \\
\text { sciences }\end{array}$ & $\begin{array}{c}\text { Mathematics } \\
\text { \& computer } \\
\text { science }\end{array}$ & $\begin{array}{c}\text { Physical } \\
\text { sciences \& } \\
\text { engineering }\end{array}$ & $\begin{array}{c}\text { Social } \\
\text { sciences \& } \\
\text { humanities }\end{array}$ \\
\hline University of Victoria & $\mathbf{5 7 . 4 \%}$ & $7.1 \%$ & $11.8 \%$ & $27.2 \%$ & $\mathbf{7 8 . 8 \%}$ & $8.4 \%$ \\
Carleton University & $49.4 \%$ & $9.7 \%$ & $8.2 \%$ & $15.0 \%$ & $\mathbf{8 6 . 2 \%}$ & $7.4 \%$ \\
Simon Fraser University & $48.8 \%$ & $12.9 \%$ & $6.7 \%$ & $31.3 \%$ & $\mathbf{7 6 . 6 \%}$ & $7.5 \%$ \\
University of Regina & $33.6 \%$ & $6.5 \%$ & $42.6 \%$ & $18.9 \%$ & $49.4 \%$ & $10.5 \%$ \\
York University & $24.2 \%$ & $11.9 \%$ & $14.1 \%$ & $26.4 \%$ & $47.9 \%$ & $10.6 \%$ \\
University of Alberta & $22.0 \%$ & $12.7 \%$ & $16.4 \%$ & $27.6 \%$ & $42.8 \%$ & $9.5 \%$ \\
Univ of British Columbia & $21.8 \%$ & $10.5 \%$ & $11.1 \%$ & $18.9 \%$ & $\mathbf{5 4 . 9 \%}$ & $9.4 \%$ \\
Univ of New Brunswick & $18.5 \%$ & $7.6 \%$ & $11.0 \%$ & $28.6 \%$ & $28.8 \%$ & $9.3 \%$ \\
University of Waterloo & $18.5 \%$ & $9.0 \%$ & $11.8 \%$ & $23.7 \%$ & $24.6 \%$ & $10.6 \%$ \\
Ryerson University & $18.4 \%$ & $10.0 \%$ & $16.0 \%$ & $24.7 \%$ & $24.5 \%$ & $12.9 \%$ \\
McGill University & $17.9 \%$ & $8.5 \%$ & $12.8 \%$ & $18.9 \%$ & $48.0 \%$ & $7.8 \%$ \\
Univ of Saskatchewan & $17.8 \%$ & $14.0 \%$ & $17.0 \%$ & $31.7 \%$ & $26.2 \%$ & $13.2 \%$ \\
University of Toronto & $17.1 \%$ & $10.8 \%$ & $12.7 \%$ & $16.2 \%$ & $49.8 \%$ & $8.4 \%$ \\
Concordia University & $16.3 \%$ & $7.4 \%$ & $12.3 \%$ & $23.3 \%$ & $21.8 \%$ & $8.3 \%$ \\
University of Manitoba & $15.4 \%$ & $12.5 \%$ & $15.4 \%$ & $28.1 \%$ & $26.8 \%$ & $10.7 \%$ \\
\hline
\end{tabular}




\begin{tabular}{|c|c|c|c|c|c|c|}
\hline University of Windsor & $15.1 \%$ & $10.3 \%$ & $9.4 \%$ & $13.7 \%$ & $21.9 \%$ & $17.3 \%$ \\
\hline Memorial Univ of Nfld & $15.0 \%$ & $11.5 \%$ & $12.8 \%$ & $28.5 \%$ & $19.5 \%$ & $6.5 \%$ \\
\hline Université de Montréal & $14.0 \%$ & $5.1 \%$ & $5.0 \%$ & $9.3 \%$ & $44.3 \%$ & $3.2 \%$ \\
\hline Queen's University & $13.9 \%$ & $9.3 \%$ & $8.6 \%$ & $16.1 \%$ & $27.4 \%$ & $8.1 \%$ \\
\hline INRS & $13.5 \%$ & $4.6 \%$ & $8.7 \%$ & $8.4 \%$ & $19.2 \%$ & $3.5 \%$ \\
\hline University of Calgary & $13.2 \%$ & $11.1 \%$ & $14.2 \%$ & $20.1 \%$ & $21.4 \%$ & $8.3 \%$ \\
\hline Western University & $12.6 \%$ & $9.3 \%$ & $11.3 \%$ & $19.7 \%$ & $24.4 \%$ & $7.3 \%$ \\
\hline McMaster University & $12.5 \%$ & $10.4 \%$ & $11.5 \%$ & $18.5 \%$ & $21.6 \%$ & $9.4 \%$ \\
\hline University of Guelph & $12.4 \%$ & $9.2 \%$ & $10.3 \%$ & $10.4 \%$ & $29.5 \%$ & $8.7 \%$ \\
\hline Dalhousie University & $11.5 \%$ & $8.3 \%$ & $11.4 \%$ & $15.9 \%$ & $23.9 \%$ & $6.9 \%$ \\
\hline University of Ottawa & $10.0 \%$ & $8.9 \%$ & $10.1 \%$ & $16.8 \%$ & $15.6 \%$ & $7.3 \%$ \\
\hline Brock University & $9.1 \%$ & $6.4 \%$ & $10.2 \%$ & $30.0 \%$ & $15.9 \%$ & $4.8 \%$ \\
\hline Univ de Sherbrooke & $6.7 \%$ & $2.9 \%$ & $3.3 \%$ & $8.3 \%$ & $14.8 \%$ & $4.3 \%$ \\
\hline Univ de Québec à Mtl & $5.3 \%$ & $4.3 \%$ & $4.7 \%$ & $7.5 \%$ & $7.5 \%$ & $4.5 \%$ \\
\hline Université Laval & $4.9 \%$ & $3.5 \%$ & $4.8 \%$ & $8.4 \%$ & $9.6 \%$ & $3.6 \%$ \\
\hline Mean & $18.9 \%$ & $8.9 \%$ & $11.9 \%$ & $19.7 \%$ & $33.4 \%$ & $8.3 \%$ \\
\hline
\end{tabular}

Table 4: Percentage of unclassified names by field (2016-2019)

This reveals a vast difference between these faculties in terms of the types of names of researchers which shows the not only the polarization of genders between fields, but also in terms of cultural diversity. It is remarkable that at Carleton University the gender of only $14 \%$ of authors publishing in the field of Physical Sciences \& Engineering can be identified. Yet on the same campus, the gender of $92.6 \%$ of the authors from the Social Sciences \& Humanities can be disambiguated. While it may not be possible to determine the percentage of women doing research at these three universities in the fields of Physical Sciences \& Engineering or in Mathematics \& Computer Science, this same inability to classify the authors' first names is an indicator of a high degree of cultural diversity in these same faculties.

Although these three universities offer the starkest contrast, the same divergence between fields is seen across all Canadian institutions. Averaged across all thirty universities, the gender of over $91 \%$ of researchers in both the Social Sciences \& Humanities as well as the Biomedical \& Health Sciences can be identified, whereas this ratio drops to $66 \%$ for the Physical Sciences \& Engineering. Thus, while the former two fields have a good balance between the genders, the latter field is characterized by greater cultural diversity.

\section{Conclusion}

This study shows how bibliometric metadata of publications can be used to measure the participation of women as active researchers at the institutional level. This analysis has shown that the rate of authorship of women in Canadian universities is on par with worldwide trends in academic research. As one-third of all authors, women make up a significant proportion of the researchers across Canada who publish.

While much progress has been made in the past fifteen years in addressing the gender imbalance in higher education, certain fields remain overwhelmingly male. The results show that the longstanding imbalance in the fields of Mathematics \& Computer Science and in the Physical Sciences \& Engineering still holds true, with only $15.6 \%$ and 
$18.0 \%$ (respectively) of authors being women. The Social Sciences \& Humanities remains the favoured discipline of female researchers with nearly half of all authors being women. Indeed, women make up a majority of authors in this field at ten Canadian universities. As there is little if any gender imbalance in the Social Sciences \& Humanities, any future increase in the ratio of women researchers in Canadian universities will need to occur in the pure and applied sciences in order to achieve overall parity. Universities have made significant progress in attracting and retaining women in these fields, and more granular data on the career trajectories of researchers in the physical sciences who are women would help to identify the hurdles faced. In particular, previous studies have showed that interruptions in the careers of women have a long-term effect on their impact and therefore qualitative studies on why some women choose to not pursue or to leave a research career (particularly in the pure and applied sciences) would provide actionable information that universities could use to address the gender imbalance.

\section{Supplemental information}

The data and calculations underlying this analysis are available at the Scholars Portal Dataverse: https://doi.org/10.5683/SP2/ZSXATA.

\section{Acknowledgements}

The author would like to thank George Duimovich (Carleton University) and Lisa Pokrajac (University of Waterloo) for their encouragement and editorial input in preparing this manuscript.

\section{About the author}

Jeffrey Demaine is the Bibliometrics and Research Impact Librarian at McMaster University, and previously held the same position at the University of Waterloo. He started his career at the National Research Council where he was an Information Scientist, continuing on in that capacity at the iFQ in Germany. His interest in this field began a quarter-century ago when he used a printed version of the Science Citation Index to do his first bibliometric analysis. He has been involved in the Bibliometrics and Research Impact Community (BRIC) conference since 2017 as both a presenter and coorganiser. His motivation is the creation of narratives from numbers.

\section{References}

Annesley, Thomas M. 2020. "Gender Authorship in the Field of Clinical Chemistry." The Journal of Applied Laboratory Medicine 5 (5): 869-876. https://doi.org/10.1093/jalm/jfaa096.

Centrum voor Wetenschap en Technologische Studies (CWTS). 2021. "Leiden Ranking 2021." https://www.leidenranking.com/.

Elsevier. 2017. "Gender in the Global Research Landscape." https://www.elsevier.com/research-intelligence/campaigns/gender-17 
Erden Aki, Ozlem, Elcin Ozcelik Eroglu, and Ece Uslu. 2015. "Longitudinal Analysis of Female Authorship of Psychiatry Articles in Turkey." Noro Psikiyatri Arsivi 52 (1): 95-98. https://www.ncbi.nlm.nih.gov/pmc/articles/PMC5353010/.

Goldstone, Kate, Carla Edgley, Sangeeta Mehta, and Kate Leslie. 2020. "Peer Review for the Canadian Journal of Anesthesia in 2016 and 2017: A Retrospective Analysis by Reviewer and Author Gender." Canadian Journal of Anesthesia 67 (3): 336342. https://doi.org/10.1007/s12630-019-01533-2.

Huang, Junming, Alexander J. Gates, Roberta Sinatra, and Albert-László Barabási. 2020. "Historical Comparison of Gender Inequality in Scientific Careers Across Countries and Disciplines." Proceedings of the National Academy of Sciences 117 (9): 4609-16. https://doi.org/10.1073/pnas.1914221117.

Kramer, Philipp W., Thomas Kohnen, David A. Groneberg, \& Michael H. K. Bendels. 2019. "Sex Disparities in Ophthalmic Research." JAMA Ophthalmology 137 (11): 1223. https://doi.org/10.1001/jamaophthalmol.2019.3095.

Larivière, Vincent, Chaogun Ni, Yves Gingras, Blaise Cronin, \& Cassidy Sugimoto. 2013. "Global Gender Disparities in Science." Nature 504 (7479): 211-213. https://doi.org/10.1038/504211a.

Lynn, Freda B., Mary C. Noonan, Michael Sauder, and Matthew A. Andersson. 2019. "A Rare Case of Gender Parity in Academia." Social Forces 98 (2): 518-547. https://doi.org/10.1093/sf/soy126.

Mattauch, Sandra, Katja Lohmann, Frank Hannig, Daniel Lohmann, and Jürgen Teich. 2020. "A Bibliometric Approach for Detecting the Gender Gap in Computer Science." Communications of the ACM 63 (5): 74-80. https://doi.org/10.1145/3376901.

Paul-Hus, Adèle., Rébecca L. Bouvier, Chaogun Ni, Cassidy R. Sugimoto, Vladimir Pislyakov, and Vincent Larivière. 2015.

"Forty Years of Gender Disparities in Russian Science: A Historical Bibliometric Analysis." Scientometrics 102 (2): 1541-1553. https://doi.org/10.1007/s11192014-1386-4.

Thelwall, Mike. 2020. "Female Citation Impact Superiority 1996-2018 in Six Out of Seven English-speaking Nations." Journal of the Association for Information Science and Technology 71 (8): 979-990. https://doi.org/10.1002/asi.24316. University of California at Los Angeles (UCLA). 2017. "Women are Making Progress Toward Gender Balance in the Social Sciences." https://socialsciences.ucla.edu/2017/08/09/women-making-progress-on-theroad-to-gender-balance-in-the-social-sciences/. 